\title{
The Role Of Sharia Banking To Recover SMEs During Covid-19 Pandemic
}

\author{
Trimulato \\ Universitas Islam Negeri Alauddin Makassar \\ Jl. Sultan Alauddin No.63, Romangpolong, Kec. Somba Opu, Kabupaten Gowa, \\ Sulawesi Selatan \\ trimsiuii@yahoo.co.id
}

\begin{abstract}
Abstrak
Tujuan penelitian untuk mengetahui perkembangan pembiayaan perbankan syariah bagi UMKM ditengah Covid-19 dan peran perbankan syariah dalam memulihkan UMKM selama pandemic. Jenis penelitian studi pustaka, menggunakan data sekunder, kemudian diolah oleh peneliti. Teknik analisis data yang digunakan dalam penelitian ini adalah deskriptif kualitatif, mendeskripsikan perkembangan pembiayaan perbankan syariah serta peran perbankan syariah bagi pemulihan UMKM di tengah wabah Covid-19. Hasil penelitian menunjukkan perkembangan pembiayaan di perbankan syariah yang disalurkan untuk UMKM selama pandemi Covid-19 mengalami penurunan. Penurunan pembiayaan terbesar terjadi pada pembiayaan BPRS untuk UMKM yang mengalami penurunan sebesar 14,88 persen, pembiayaan BUS untuk UMKM mengalami penurunan sebesar 14,17 persen, dan pembiayaan UUS mengalami penurunan sebesar 13,47 persen. Peran perbankan syariah bagi pemulihan UMKM di tengah pandemi covid-19 adalah meningkatkan porsi pembiayaan UMKM, mendampingi mereka para pelaku sebagai mitra, perbankan syariah dapat memberikan keringanan pembayaran, meningkatkan jumlah pembiayaan skema bagi hasil yang lebih tepat untuk pembiayaan UMKM.
\end{abstract}

\section{Kata Kunci: Bank Syariah, UMKM, Pandemi Covid-19}

\begin{abstract}
The purpose study to determine development sharia banking financing for SMEs during covid-19 pandemic. Then to find role sharia banking recover SMEs during covid-19 pandemic. Type research used library research, data source used secondary data, which has published institutions processed researchers and from various preexisting sources. Data analysis technique used research descriptive qualitative, describing development financing sharia banking and role of sharia banking for recovery SMEs during covid-19 pandemic. Results showed development of financing in sharia banking was distributed SMEs during covid-19 pandemic experienced decrease amount of financing. Largest decline in financing occurred in BPRS financing for SMEs, which experienced decline of 14.88 percent, BUS financing investment SMEs decrease 14.17 percent, and UUS financing decrease 13.47 percent. Role sharia banking recovery SMEs during covid-19 pandemic is increasing portion financing SMEs, assisting them players as partners, sharia banking can provide payment, increasing number financing profit-sharing schemes more appropriate for financing SMEs.
\end{abstract}

\section{Keywords: Sharia Banking, SMEs, and Covid-19 Pandemic}




\section{The Role Of Sharia Banking To Recover SMEs \\ During Covid-19 Pandemic}

Trimulato

\section{INTRODUCTION}

One of the main functions of sharia banking is to channel financing to the public as regulated in the sharia banking law number 21 of 2008. The distribution of this financing is one of the main businesses and therefore the main source of income for sharia banking. In line with the relatively new development of sharia banking in Indonesia, sharia financing with all types of contracts and characteristics is still not well understood by the public and even the employees and officials of sharia banking themselves. Financing channeled by sharia banking is expected to contribute to sustainable income and is always in good quality during its period. The quality of financing that is not good, or even deteriorating, will have a direct impact on the decline in revenue and profit earned by sharia banking. The decline in revenue and profit further reduced the ability of sharia banking to channel further financing and run other businesses. (Ikatan Bankir Indonesia. 2015)

The ability of bank to channel financing to the business sector must be supported by the ability of bank to collect funds from the public, if people have confidence in the banking industry, then they will place their funds in the bank. The higher the level of public trust, the funds raised by banks will increase which will have an impact on the increase in bank liquidity to channel financing to entrepreneurs so that the real sector can move to support the country's development. As an intermediary institution, banks function to channel funds originating from savers (deposits) to people who need capital for their business (debtors). The definition of a bank is also an agent of development, which can encourage development progress through credit facilities and ease of payments and withdrawals in the transaction process carried out by economic actors.(Nugroho, et al. 2020)

Islamic financial and banking institutions should strive to promote development by being more actively involved in financial and agricultural institutions. The purpose of Islamic banks, in general, is to encourage and accelerate the economic progress of a society by conducting banking, financial, commercial, and investment activities according to sharia principles. This is what distinguishes it from conventional banks whose main goal is to achieve the 
highest profit (profit maximization). Because of their sharia-based nature, sharia bank products are not the same as conventional bank products, namely the prohibition of using the bank interest system, which is categorized as usury, the prohibition of making transactions that contain elements of maysir, gharar (uncertainty), and false. Sharia banking products are classified based on four categories of agreements known in Islam. In Islamic banking, every product issued is based on the principles of deposit, sale and purchase, leasing, profit sharing, and social contracts (tabarru). According to Muhamad, in the operating system of a sharia bank, the owner of funds invested in the bank was not based on an interesting motive, but rather on the desire to get a profit in the form of profit sharing. The customer funds are then distributed to those in need, for example, an entrepreneur who wants to start or expand his business activities. Profit-sharing is based on the profit-sharing ratio agreed upon at the beginning of the contract.(Uman and Budi. 2017)

Ideally, sharia banking are universal banks that not only offer deposit and financing products but also capital participation in their customers' business activities. Conceptually, a sharia banking can carry out unlimited participation in a company where participation is carried out continuously and the bank places the position of the company where it is investing as one of the strategic business units. However, if this is implemented, it will require a change in perspective regarding the position of sharia banking as an intermediary institution that provides financial services following sharia principles. Based on the banking law which currently also applies to sharia banking, equity participation can only be limited to financial institutions. Equity participation in non-financial institutions may only be undertaken in the context of settling problematic financing which is temporary. Sharia banking, like conventional banks, can provide financing for both production and consumption activities. There are three main types of products in terms of the distribution of funds, namely financing based on the principle of profit-sharing (investment), buying and selling, and leasing. Also, sharia banking in Indonesia are still a minority in the national banking system so that they have always been a market follower in pricing banking products. The result is a growing perception in society that 


\section{The Role Of Sharia Banking To Recover SMEs \\ During Covid-19 Pandemic}

Trimulato

sharia banking are the same as conventional banks. In addition to direct financing, sharia banking can carry outplacement activities by purchasing sharia-based securities, taking over accounts receivable, purchasing commodities, placing them in sharia interbank transactions as well as financing/loans without compensation (benevolent loan). (Darsono, et al. 2017) Several research results indicate that bank and non-bank financial institutions that are formal and operate in rural areas generally cannot reach people from the middle to lower economic class. This inability is primarily in terms of assuming risks and operating costs, as well as in business identification and monitoring of use in business-worthy credit. This inability of financial institutions is the cause of the vacancies in the financial market segment in rural areas. As a result, $70 \%$ to $90 \%$ of these vacancies are filled by non-formal financial institutions, including loan sharks, using very high-interest rates to cope with incidents such as the need for an institution that can be a middle way. The real form is to increase the operation of financial institutions with the principle of profit-sharing, such as the Sharia Financing Bank (BPRS) and Baitul Maal Wattamwil (BMT). (Muhamad. 2012)

In the process of its journey, Islamic banking has distributed a lot of financing which is still dominated by consumer needs. Productive activities have not become a priority for the distribution of financing in sharia banking. This can be seen from the distribution of financing in sharia banking which is still dominated by consumptive financing. Also, the portion of financing with a profit-sharing scheme, which is the identity of sharia banking, has not become the main one but is still dominated by financing with a buying and selling scheme which is widely used for consumption purposes. The distribution of productive financing indirectly has not been maximized, without the exception of the financing channeled for the development of SMEs. The distribution of funding for SMEs has not received a large portion. Especially during the current conditions, since the emergence of the Covid-19 pandemic which had an impact on financial institutions including sharia banking themselves, and also hit SMEs players. The decline in the work of sharia banking and the bad impact of SMEs during the Covid-19 pandemic made the need for sharia banking to survive and increased their role to be able to restore and contribute to the country's 
economy in abnormal conditions, different from before. The emergence of the covid-19 outbreak has made Islamic banks experience a decline in performance, many financing customers have proposed repairing financing, due to the impact, so that it is difficult to fulfill their obligations. Covid-19 has also had a bad impact on the sustainability of SMEs, both in regions and in cities. Covid-19 provides adaptation to new habits, the existence of a ban on gathering, rules on guarding distance, working from home, resulting in slowing economic activity, including for SMEs players, including many institutions that have been closed since this outbreak. The Covid-19 outbreak has badly affected Islamic banks and SMEs so that both must be able to survive and improve their performance in current conditions. There needs to be an effort that must be made by sharia banking to improve their performance, including increasing their role in economic development, including for SMEs.

The impact of the Covid-19 pandemic on the banking intermediation function, based on the results of a comparative study on Bank Syariah Mandiri, Bank Mega Syariah, Bank Syariah Bukopin, Bank Victoria Syariah, and BJBSyariah show that the intermediation function of the Bank, namely Financing and Third Party Funds, all Banks show turmoil. On the financing side, Bank Syariah Mandiri and Bank Mega Syariah during January to March 2020 tend to increase. Meanwhile, Bank Bukopin Syariah, Victoria Bank Syariah, and Bank BJB Syariah showed fluctuation. On the side of the collection of funds (DPK), Bank Syariah Bukopin showed a decline from January to March 2020. Meanwhile, Bank Mandiri Syariah, Bank Mega Syariah, Bank Syariah BJB, and Bank Victoria Syariah showed fluctuation. (Mardhiyaturrositaningsih \& Syarqim. 2020)

The covid-19 pandemic currently occurring inevitably affects various sectors. At the global economic level, the covid-19 pandemic has a very significant impact on the domestic economy of the nation-state and the existence of SMEs. The Organization for Economic Co-operation and Development (OECD) report states that this pandemic has implications for the threat of a major economic crisis marked by the cessation of production activities in many countries and falling levels of public consumption. No country 


\section{The Role Of Sharia Banking To Recover SMEs \\ During Covid-19 Pandemic}

Trimulato

can predict when the covid-19 pandemic will end. A simple way to adapt and deal with this pandemic is to prepare short-term and long-term strategies while continuing to hope that a vaccine for the covid-19 pandemic will soon be discovered and mass-produced. The short-term policy that can be implemented is financial assistance in the form of soft loans or direct cash assistance by involving the government and the private sector. Meanwhile, the long-term strategy is focused on the introduction and use of digital technology for SMEs as well as preparation for entering the Industrial 4.0 era.(Aknol. 2020)

Leading business capital assistance during a crisis, not a few business sectors or Micro, Small and Medium Enterprises (SMEs) are struggling to survive. This business is often difficult to survive due to limited capital. The existence of SMEs as a non-muzakki group is a group that is very vulnerable to falling into the abyss of poverty and bankruptcy due to economic shocks or impacts. Therefore, providing capital to businesses is used as a means of reducing the impact of the crisis. This provision of capital can be done with several policy alternatives, such as providing additional stimulation of sharia banking relaxation and restructuring or deferral of sharia credit/financing payments for the next few months. The provision of capital from Islamic banking / financial institutions needs to be supported and strengthened with assistance so that it can be accounted for. The above business capital can also be followed by a qardhul hasan loan. In sharia economic/financial terminology, qardhul hasan is a loan that does not take any benefits (profits) but is still emphasized to be repaid. This product/scheme is one of the products / schemes of the Islamic financial system which is very important in supporting the recovery or sustaining the economy. Among the distribution options that can be done are through: (1) Sharia Microfinance Institutions in financing nano businesses where the funds can come from several sources, both from the general public, private companies, and BUMN / BUMD; (2) direct loans without margin for both business and consumption that are channeled by companies (private or BUMN / BUMD) to employees or partners (such as online motorcycle taxi drivers) where the funds can come from Corporate Social Responsibility (CSR) funds or other posts. To increase CSR funds, the government needs to emphasize the obligations and higher CSR contributions 
from both BUMN / BUMD and private companies. Islamic banking sector and qardhul hasan, some of the funds collected by units or organizations that collect zakat, especially those in the regions, can be used to strengthen SMEs businesses. Saving the SMEs group that is in crisis or is threatened with bankruptcy due to the economic impact of the covid-19 pandemic, can be categorized as the asnaf (zakat recipient) group, namely as a poor group, struggling in the path of Allah (fii sabilillah), or people in debt (gharimin). The development of sharia financial technology to smooth liquidity of online market players in sharia, while at the same time efforts are made to increase the focus on social finance (zakat, donations, alms, and waqf) in addition to commercial finance. Including the development of a market place to gather traditional markets and SMEs, which currently number nearly 60 million, to bring together demand and supply both domestically and abroad, especially in times of lockdown due to pandemics. In particular, direct cash assistance, zakat, infaq, waqf, or CSR, both for the community and the business sector or SMEs, can be encouraged, so these efforts are expected to increase aggregate demand and aggregate supply to the right (in the demand and supply curve). followed by the development of an online market that focuses on SMEs that reconcile demand and supply, so that the economic surplus is re-established and helps accelerate economic recovery. (https://www.kemenkeu.go.id)

The impact felt by sharia banking and SMEs players due to the impact of the covid-19 pandemic, responds to the role of regulatory institutions that can maintain economic conditions so that they are well maintained. The Financial Services Authority has issued POJK Regulation Number 11 / POJK.03 / 2020, regarding the National Economic Stimulus as a Countercyclical Policy on the Impact of the Spread of Covid-19. The development of the spread of the coronavirus disease 2019 (covid-19) has a direct or indirect impact on the performance and capacity of debtors including micro, small and medium business (SMEs) debtors, thus potentially disrupting banking performance and financial system stability which can affect economic growth. Therefore, to encourage optimization of the banking intermediation function, maintain financial system stability, and support economic growth, and economic stimulus 


\section{The Role Of Sharia Banking To Recover SMEs \\ During Covid-19 Pandemic}

Trimulato

policy is needed as a countercyclical impact on the spread of covid-19. The main points of POJK Regulation on the Stimulus of the Impact of covid-19 include a. This POJK applies to BUK, BUS, UUS, BPR, and BPRS. b. Banks can implement policies that support economic growth stimulus for debtors affected by the spread of covid-19, including SMEs debtors, while still paying attention to the principle of prudence. c. Debtors affected by the spread of covid-19 including SMEs debtors are debtors who have difficulty fulfilling obligations to the Bank because the debtor or debtor's business is affected by the spread of covid-19, either directly or indirectly in the economic sector, including tourism, transportation, hospitality, trade. processing, agriculture, and mining. d. The stimulus policies consist of 1) Assessment of the quality of credit/financing other provision of funds based solely on the accuracy of principal and/or interest payments for credit/financing other provision of funds with a ceiling of up to Rp1o billion, and 2) Improvement of credit/financing quality to become smooth after restructuring during the validity period of POJK. This restructuring provision can be applied by the Bank regardless of credit/financing ceiling limits or the type of debtor. e. The way of restructuring credit/financing is carried out as stipulated in the OJK regulations regarding asset quality assessment, among others by 1) lowering interest rates; 2) extension of the period; 3) reduction of principal arrears; 4) reduction of interest arrears; 5) additional credit/financing facilities; and/or 6) credit/financing conversion to Temporary Equity Participation. f. Banks can provide new credit/financing provision of funds to debtors who have received special treatment following this POJK by determining the quality of credit/financing other provision of funds carried out separately from the quality of previous credit/financing provision of funds. (https://www.ojk.go.id)

From the description above, the researchers are interested in conducting deeper research related to the role of sharia banking for economic recovery, especially for SMEs during Covid-19 pandemic. The purpose of this study is to determine the development of financing channeled by sharia banking during the pandemic. Then to find out the role of Islamic banking for the economic recovery of SMEs during the covid-19 outbreak. 


\section{LITERATURE REVIEW}

Singgih Muheramtohad in his research entitled The Role of Islamic Financial Institutions in Empowering SMEs in Indonesia. Mention that the characteristics of SMEs are relatively low turnover, have makeshift equipment (traditionaly/manual), and have a narrower market share. They also need capital to develop a business. This field is what Islamic financial institutions need to fill. Where in Islamic law, the financing sector for real business is practiced directly, both by the Prophet and by the Prophet's companions, including Umar Ibn Khattab. Providing financing to SMEs is more effective because it is allocated directly to the needs of small businesses. Another consideration that must be considered by the government is that the philosophical foundation of this country is Pancasila. In this case, the state is based on social justice for all Indonesian people. (Muheramtohad. 2017)

Azwar Iskandar, et al in his paper entitled The Role of Islamic Social Economics and Finance during the covid-19 pandemic stated that as a country with the largest Muslim population in the world, Muslims can provide their best role through various forms or models of philanthropy in Islamic economics and finance, especially in during the covid-19 pandemic. This role is expected to be able to overcome the economic shocks that occur and the entire community, especially Muslims, can participate in contributing to recovering these shocks. Among the solutions that can be offered within the framework of the concept and system of Islamic Social Economics and Finance are: (1) by distributing direct cash assistance originating from zakat, donations, and alms; (2) by strengthening waqf in the form of cash waqf, productive waqf, waqf linked Sukuk and waqf for infrastructure; (3) through superior business capital assistance for the business sector or Micro, Small and Medium Enterprises (SMEs); (4) through the qardhul hasan scheme; (5) increasing Islamic economic and financial literacy; (6) through the development of Islamic financial technology. If the aforementioned programs, especially direct cash assistance, zakat, infaq, waqf, or CSR, can be promoted, it is hoped that this will help the economic surplus be re-established so that the acceleration of economic recovery can be realized. (Azwar Iskandar, et al. 2020) 


\section{The Role Of Sharia Banking To Recover SMEs \\ During Covid-19 Pandemic}

Trimulato

Muhammad Ubaidillah and Rizqon Halal Syah Aji in their paper entitled Review of the Implementation of the Extension of the Angsusran Period for Financing in Sharia Banks in the covid-19 pandemic Situation, stated that the $\mathrm{Al}$-Baqarah verse $28 \mathrm{o} \mathrm{Al}$-Quran has provided financial solutions to creditors to provide concessions to affected debtors Covid-19. This paragraph has been translated into formal regulations in Indonesia, namely Law Number 2 of 2020 and POJK Number 11/POJK.03 / 2020. These two regulations are the legal basis for banks to provide credit restructuring or financing to debtors affected by the Covid-19 pandemic. Credit or financing restructuring needs to be provided so that the level of public consumption is maintained and does not experience a major decline. When the level of consumption can be maintained, then economic growth can also be maintained at an optimal level. However, these regulations are not sufficient if implementation in the field is not following what has been declared. Therefore, the Government must be present in-person to monitor the implementation of the regulations it has made. (Ubaidillah and Rizqon. 2020)

Binti Nur Aisyah, et al, in their research entitled The Prohibition of Riba in Banking: Impact on the Realization of Welfare in the Covid-19 Period, concluded that the problems caused by the interest system (usury), namely: there is injustice in economic practices. This was felt when covid19 hit. Customers find it difficult to get profit, while bank interest must be paid every month. Interest in conventional banks is a supporter of bad credit in conventional banking, high credit rates, and many times it results in difficulties for customers to pay, and people's economic life is uncertain. This interest is one of the factors causing inflation and the emergence of economic disparities and wealth conglomerates. Because of that, the DSN, in its fatwa No. 1 of 2004, punishes interest as usury. Efforts to prevent people from using the above usury practices, sharia banking provide a solution by implementing a profit-sharing system. The profit-sharing system has a fair and welfare effect. The impact of economic justice makes the economy evenly distributed, inflation will adjust as people's purchasing power increases, and with a prosperous society, people will avoid consumptive debt. (Aisyah, et al. 2020) 
Sharia banking is a bank that carries out all business operations based on shari'ah principles, namely the rules of an agreement based on Islamic law between a bank and other parties for depositing funds and/or financing business activities, or other activities that are stated following sharia principle. In running its business, the sharia banking uses a profit-sharing pattern which is the main basis in all its operations, both in products of raising funds, financing, and in other products. Sharia banking products have similarities but are not the same as conventional bank products because of the prohibition of riba, gharar, and maysir. Therefore, products for raising funds and financing at sharia banking must avoid these prohibited elements. (Ascarya. 2007)

Sharia banking according to law number 21 of 2008 are Sharia Banking are Banks that carry out their business activities based on Sharia Principles and by type consist of Sharia Commercial Banks and Sharia Rural Banks. Sharia principles are principles of Islamic law in banking activities based on fatwas issued by institutions that have the authority to determine fatwas in the field of sharia.

According to law number 20 of 2008 , it is stated that a micro business unit is a productive business owned by an individual and/or an individual business entity that meets the criteria of a micro business as regulated in the law. Micro businesses are businesses that are managed by individuals or families or some people who do not have a complete business license (Nizarul. 2014)

Small companies are managed or led by the company owner. The company's organizational structure is simple and there are still many concurrent positions. The probability of company failure is relatively high. Businesses find it difficult to develop because of the difficulty of obtaining loans on soft terms. How to develop a small company, namely; promote a sense of business in the community. Then provide bank credit assistance on soft terms to small entrepreneurs. Then improve skills and expand job opportunities. Furthermore, forming and activating small industrial centers. As well as reducing capital-intensive investment and encouraging the business partner system of "foster father" of large to small companies. Finally, forming a business 


\section{The Role Of Sharia Banking To Recover SMEs \\ During Covid-19 Pandemic}

Trimulato

incubator to facilitate the development of budding entrepreneurs. (Susatyo and Bambang, 2014).

It is known that the private sector is dominated by micro-scale enterprises. This also means that there is a lot of public interest in opening a business or becoming an entrepreneur. Next is how to make micro-scale businesses able to reach a large scale, to improve national economic conditions. Based on the contribution of SMEs to the Gross Domestic Product (GDP) of the sector, it can be seen that the largest contribution of SMEs is in the Agriculture, Animal Husbandry, Forestry and Fisheries (PPKP) sector with the SMEs unit of 49.58 percent, followed by the Trade, Hotel and Restaurant sector (PHR) of 29.56 percent. The industry in this sector has the potential to be developed from micro, and there is an opportunity to be developed into a large industry. (Irfan and Laily. 2016)

SMEs are seen from the net worth and total annual sales of productive businesses owned by individuals and / or business entities that are not larger subsidiaries (Law No. 20/2008 on UMKM). Micro businesses have a maximum net worth of IDR 50 million. Maximum annual sales of IDR 300 million. Meanwhile, small businesses are those that have a net worth between Rp. 50 million - 500 million. Sales in oneyear reach Rp. 300 million to Rp. 2.5 billion. Meanwhile, medium-sized businesses have a net worth of Rp. 500 million - 10 billion. Annual sales reach IDR 50 billion. The Central Statistics Agency (BPS) classifies businesses based on the number of workers. Household businesses have a maximum of 5 workers. Small and medium enterprises have 6 to 19 workers. Medium enterprises have 20 to 29 workers. If there are more than 100 workers, it is classified as a large business which does not include SMEs. (Bappaenas. 2018)

\section{METHODS}

The type of research used in this research is library research, from several pre-existing sources presented by an institution that is considered relevant to the research theme. The nature of the research in this study is qualitative, which describes the object in a study, in this case, it describes the SMEs financing 
channeled by Islamic banks during the Covid-19 pandemic. Then the role of sharia banking in restoring SMEs during covid-19 pandemic.

The data source in this study is secondary data, namely data obtained from several sources both from data that have been presented by certain institutions, which are then processed by researchers. Includes data sources from books, journals, websites, and others deemed relevant to the research theme. Furthermore, the data collection techniques used in this research are through several methods, namely: Literature Study This method is used to explore the basics of theory related to sharia banking institutions and SMEs and related to the role of sharia banking for SMEs. Then Observation Each data obtained from various sources is observed and analyzed in relation to the development of Islamic bank financing. Data issued by the Financial Services Authority which is then processed by the author.

The limitation of this study is the financing channeled by Islamic banks to SMEs during the covid-19 pandemic. Financing products owned by sharia banking for SMEs. The data analysis technique used in this research is descriptive qualitative, the data obtained will be processed by the researcher then the data obtained will be described, data related to the development of financing in sharia banking for SMEs during the covid-19 pandemic, then the role of sharia banking in restoring the economy in particular for SMEs.

\section{DISCUSSION}

Development of Financing in Sharia Banking for SMEs

Table 1

Financing of Sharia Banking March 2020 - July 2020

\begin{tabular}{|c|c|c|c|c|c|}
\hline No & $\begin{array}{l}\text { Type Of Sharia } \\
\text { Banking }\end{array}$ & Purposes & March 2020 & July 2020 & Growth \\
\hline 1 & $\begin{array}{l}\text { Sharia } \\
\text { Commercial } \\
\text { Bank }\end{array}$ & $\begin{aligned} & \text { 1. } \text { Consumption (Not } \\
& \text { SMEs) } \\
& \text { 2. Working Capital } \\
& \text { a. SMEs } \\
& \text { b. Non SMEs } \\
& \text { 3. Investment } \\
& \text { a. SMEs } \\
& \text { b. Non SMEs }\end{aligned}$ & \begin{tabular}{ll}
\multicolumn{2}{l}{$95.896,99$} \\
a. & $37.474,54$ \\
b. & $42.068,94$ \\
& \\
a. & $23.930,10$ \\
b. & $\mathbf{2 9 . 0 2 3 , 3 4}$
\end{tabular} & \begin{tabular}{ll}
\multicolumn{2}{|c|}{$99.864,90$} \\
& \\
a. & $35 \cdot 522,32$ \\
b. & $43 \cdot 995,81$ \\
& \\
a. & $\mathbf{2 0 . 5 3 9 , 5 8}$ \\
b. & $34 \cdot 791,69$
\end{tabular} & $\begin{array}{ll}\text { a. } & -\mathbf{5 , 2 1} \\
\text { b. } & \mathbf{4 , 5 8} \\
& \\
& \\
\text { a. } & -\mathbf{1 4 , 1 7} \\
\text { b. } & 19,87\end{array}$ \\
\hline 2 & $\begin{array}{l}\text { Sharia } \\
\text { Business Unit }\end{array}$ & $\begin{array}{ll}\text { 1. } & \text { Consumption (Not } \\
\text { SMES) } \\
\text { 2. Working Capital }\end{array}$ & $67.375,30$ & $68.148,90$ & $1,15 \%$ \\
\hline
\end{tabular}




\section{The Role Of Sharia Banking To Recover SMEs}

During Covid-19 Pandemic

Trimulato

\begin{tabular}{|c|c|c|c|c|c|}
\hline & & $\begin{array}{ll}\text { a. } & \text { SMEs } \\
\text { b. } & \text { Non SMEs } \\
\text { 3. Investament } \\
\text { a. SMEs } \\
\text { b. Non SMEs } \\
\end{array}$ & $\begin{array}{lr}\text { a. } & 8.741,04 \\
\text { b. } & 22.879,19 \\
& \\
\text { a. } & 5.042,74 \\
\text { b. } & 29.219,33 \\
\end{array}$ & $\begin{array}{lr}\text { a. } & 7.563,12 \\
\text { b. } & \mathbf{2 6 . 3 0 1 , 2 6} \\
& \\
\text { a. } & 4.853,77 \\
\text { b. } & \mathbf{2 7 . 3 0 7 , 3 5} \\
\end{array}$ & $\begin{array}{ll}\text { a. } & -13,47 \\
\text { b. } & 14,96 \\
& \\
\text { a. } & -3,75 \\
\text { b. } & -6,45 \\
\end{array}$ \\
\hline 3 & $\begin{array}{l}\text { Financing of } \\
\text { Sharia Rural } \\
\text { Bank }\end{array}$ & $\begin{array}{ll}\text { a. } & \text { SMEs } \\
\text { b. } & \text { Non SMEs }\end{array}$ & $\begin{array}{ll}\text { a. } & 6.108,145 \\
\text { b. } & 4.570,174\end{array}$ & $\begin{array}{l}\text { a. } 5 \cdot 199,269 \\
\text { b. } 5 \cdot 336,271\end{array}$ & $\begin{array}{ll}\text { a. } & -14,88 \\
\text { b. } & 16,76\end{array}$ \\
\hline 4 & Total & & $372.329,83$ & $379.424,24$ & $1,91 \%$ \\
\hline
\end{tabular}

Source: Financial Services Authority. Sharia Banking Statistics July 2020 (Processed Data)

From the data above, it shows the development of financing disbursements carried out by sharia banking since the emergence of the covid19 pandemic, namely in the period March 2020 to July 2020. The data shows the distribution of financing to sharia banking for consumption, business capital, and investment needs. Types of sharia banking consist of Sharia Commercial Banks (BUS), Sharia Business Units (UUS), and Sharia Rural Banks (BPRS). Types of financing channeled for SMEs and Non-SMEs businesses. Overall total financing only grew by 1.91 percent. For the distribution of SMEs financing from the three types of sharia banking, it went downhill, the largest decrease in BPRS, the decline for SMEs reached 14.88 percent. Working capital SMEs financing BUS has decreased by -5.21 percent, and investment for SMEs has decreased by 14.17 percent. Furthermore, for UUS, it experienced a decrease for SMEs, working capital had decreased by 13.47 percent and investment for MSMEs had decreased by -3.75 percent. In terms of the distribution of sharia financing to SMEs during the covid-19 period, it experienced a lot of declines, while financing for non-SMEs consumption tended to continue to grow during the covid-19 period. In current conditions, sharia banking should be able to play a role in helping the existence of SMEs which are currently being affected by the covid-19 outbreak, sharia banking as intermediaries should show their role as partners who can assist and guard the recovery of SMEs who are currently experiencing difficulties. It is time for sharia banking to play a role in increasing their financing for SMEs, many players need, besides business capital, assistance and guidance so that businesses can grow back and rise from the impact of covid-19 pandemic. 


\section{The Role Of Sharia Banking To Recover SMEs During Covid-19 Pandemic}

Sharia banking an intermediary institution, which collects funds from the public and distribute them to the public, with various financing schemes it has. As the objectives of financing in sharia banking consist of consumptive and productive purposes, while the productive objectives consist of two, namely working capital and investment. During the covid-19 outbreak which has an impact on the performance of sharia banking, a strategy is needed so that companies can survive and improve their performance. In a larger scope, Sharia banking has a role in restoring the economy that was affected by the impact of the covid-19 outbreak, sharia banking must prove to be able to withstand the current crisis storm. Distribution of financing in sharia banking which are still dominated by consumer financing, in the current conditions of the covid-19 outbreak, sharia banking have been able to increase their financing for productive purposes. Many business players have been affected by the covid-19 outbreak, sharia banking can be there to support these efforts to prove their role as an intermediary institution that supports the development of the real sector. The current condition is that many businesses need assistance, what is needed is not just additional capital, but more intense assistance between sharia banking and their customers who are affected by covid-19 resulting in a decrease in income. Another role that Islamic banks can play is as instructed by the OJK so that Islamic banks provide relief for customers affected by covid-19, sharia can become advisors in developing their customers' businesses.

The role of sharia banking is needed to restore the economy, especially for SMES players. The character of SMEs business is very appropriate with sharia banking which increase the real sector. Sharia banking have financing with profit-sharing schemes that conventional banks do not have, this scheme is more appropriate for sharia banking to increase their financing for SMEs, uncertain economic conditions like today, profit-sharing schemes are more appropriate for SMEs financing and fair. The relationship between sharia banking is not limited to creditors and debtors as is the case, but more than that there is a partnership between the two parties, resulting in sharia banking being 


\section{The Role Of Sharia Banking To Recover SMEs \\ During Covid-19 Pandemic}

Trimulato

able to provide maximum assistance and assistance for customers who have businesses, sharia banking can provide good advice and advice related to sales, management, and business development processes for partner customers. The role of sharia banking for the recovery of SMEs through improving their digitalbased services. If so far sharia banking have utilized technology for fund-raising services or only for third-party customers, in current conditions sharia banking can improve technology services for financing customers, including SMEs financing customers. Technology services for financing customers in the form of easier financial access, special banking transactions for SMEs players, as well as digital services for SMEs customers who can market their products through an online system, including training that supports the business of SMEs customers, including good financial reporting.

\section{CONCLUSION}

The development of sharia banking financing for SMEs since the emergence of the covid-19 pandemic, from March 2020 to July 2020, financing is still dominated by consumer financing. Sharia banking product inancing for SMEs has decreased, in Islamic Commercial Banks (BUS) working capital financing for SMEs has decreased by -5.21 percent, and investment financing for SMEs has decreased by -14.17 percent. As for the sharia bank, the type of Sharia Business Unit financing for SMEs has also decreased, working capital financing has decreased by -13.47 percent and investment financing for SMEs has decreased by -3.75 percent. Then the Sharia Rural Bank financing distribution for SMEs has decreased by -14.88 percent.

Sharia banking have a role in economic recovery, especially for SMEs, due to the impact of covid-19, which is aimed at increasing the real sector. The role of sharia banking in the recovery of SMEs is in the form of providing relief for customers affected by covid-19 as per applicable OJK regulations. Assistance to SMEs financing customers can be carried out more by sharia banking as partners, providing input and suggestions for business development. The condition of Covid-19 requires sharia banking to increase the volume of financing with a profit-sharing scheme for SMEs financing customers, this scheme is fairer. The role of sharia banking in the recovery of SMEs is through 
improving digital-based services, online-based services for SMEs financing customers, customers can make online sales, can report financial online, and information that customers can access to improve their business again sharia banking have a major role in the recovery of SMEs, by maximizing the productive financing they have, increasing SMEs financing and minimizing consumer financing.

\section{REFERENCES}

Aisyah, B.N. et al. (2020). Pelarangan Riba Dalam Perbankan: Impact Pada Terwujudnya Kesejahteraan di Masa Covid-19. Batusangkar: Jurnal IMARA, Jurnal Penelitian Ekonomi Islam. Volume 4. Nomor 1. Fakultas Ekonomi dan Bisnis Islam IAIN Batusangkar. p.10.

Alim, Nizarul. (2009). Pembiayaan Syari'ah untuk Usaha Mikro dan Kecil: Studi Kasus Dan Solusi, Cet. I Surabaya: PT. Bina Ilmu.

Darsono, etc al. (2017). Masa Depan Keuangan Syariah Indonesia. Jakarta: Tazkia Publishing. p.128.

Herlambang, S and Bambang H.W. (2014). Pengantar Ilmu Bisnis. Yogyakarta: Parama Publishing.

Ikatan Bankir Indonesia (IBI). (2015). Mengelola Bisnis Pembiayaan Bank Syariah. Jakarta: PT Gramedia Pustaka Utama. p.2.

Kementerian Perencanaan Pembangunan Nasional/Badan Perencanaan Pembangunan Nasional. (2018). Masterplan Ekonomi Syariah Indonesia 2019-2024 Hasil Kajian Analisis Ekonomi Syariah di Indonesia.

Kristian, A.P. (2020). COVID-19 dan Implikasi Bagi Usaha Mikro, Kecil, dan Menengah. Parahyangan : Jurnal Ilmiah Hubungan Internasional. Universitas Katolik Parahyangan. Volume Volume 16 Nomor 1. Universitas Katolik Parahyangan.

Law Number 20, 2008. About SMEs.

Law Number 21. 2008. About Sharia Banking.

Mardhiyaturrositaningsih \& Syarqim.,M.,M. (2020). Dampak Pandemi Covid-19 Terhadap Manajemen Industri Perbankan Syariah: Analisis Komparatif. Maros: POINT: Jurnal Ekonomi dan Manajemen. Vol. 2, No. 1. Program Studi Manajemen, Fakultas Ekonomi dan Bisnis Universitas Muslim Maros.

Muhamad. (2012). Teknik Perhitungan Bagi Hasil Dan Pricing di Bank Syariah. Yogyakarta: UII Press. p.4.

Muheramtohad, S. (2017). Peran Lembaga Keuangan Syariah dalam Pemberdayaan UMKM di Indonesia. Salatiga: Jurnal Muqtasid, Jurnal Ekonomi dan Perbankan Syariah. IAIN Salatiga Volume 8, Nomor 1. 


\section{The Role Of Sharia Banking To Recover SMEs During Covid-19 Pandemic}

Trimulato

Nugroho, L., et al. (2020). Pengantar Perbankan Syariah. Bandung: Widina Bhakti Persada. p.17.

Otoritas Jasa Keuangan. Statistic of Sharia Banking on July 2020.

Syauqi, I. B and Laily, D.A. (2016). Ekonomi Pembangunan Syariah. Jakarta: PT RajaGrafindo Persada.

Ubaidillah, M., \& Halal, R., S., A. (2020). Tinjauan Atas Implementasi Perpanjangan Masa Angsusran Untuk Pembiayaan di Bank Syariah Pada Situasi Pandemi Covid-19. Palembang: Islamic Banking : Jurnal Pemikiran dan Pengembangan Perbankan Syariah. Volume 6. Nomor 1. Prodi Perbankan Syariah STEBIS IGM Palembang.

Umam, K and Setiawan B.M. (2017). Perbankan Syariah Dasar-dasar Dinamika Perkembangannya di Indonesia. Depok: PT RajaGrafindo Persada. p.65.

https://www.kemenkeu.go.id/publikasi/artikel-dan-opini/solusi-ekonomi-dankeuangan-islam-saat-pandemi-covid-19/, accesed $26^{\text {th }}$ October 2020.

https://www.ojk.go.id/id/regulasi/Documents/Pages/Stimulus-PerekonomianNasional-Sebagai-Kebijakan-Countercyclical-Dampak-PenyebaranCoronavirus-Disease-2019/Ringkasan. Accesed $26^{\text {th }}$ October 2020. 